Bayero Journal of Pure and Applied Sciences, 6(1): $174-178$

Received: November 2012

Accepted: June 2013

ISSN $2006-6996$

\title{
CHROMIUM, NICKEL AND ZINC LEVELS FROM CANNED AND NON-CANNED BEVERAGES IN ZARIA, KADUNA STATE, NIGERIA
}

\author{
${ }^{*}$ Garba ${ }^{1}$, Z.N., Ugbaje ${ }^{1}$, C., Abdullahi, ${ }^{1}$ A.K. and Garba, N.N. ${ }^{2}$ \\ ${ }^{1}$ Department of Chemistry, Ahmadu Bello University, P.M.B. 1044, Zaria, Nigeria. \\ ${ }^{2}$ Department of Physics, Ahmadu Bello University, P.M.B. 1044, Zaria, Nigeria. \\ ${ }^{*}$ Correspondence author: dinigetso2000@gmail.com
}

\begin{abstract}
Heavy metals (Chromium, Nickel and Zinc) were determined from both canned and non-canned beverages sold in Samaru, Zaria, Kaduna State, Nigeria. Concentration of Chromium was found to range from $0.528-1.509 \mathrm{mg} / \mathrm{L}$ for canned and $0.176-1.358 \mathrm{mg} / \mathrm{L}$ for non-canned beverages, Nickel concentration was found to range from $0.156-0.802 \mathrm{mg} / \mathrm{L}$ for canned and $0.125-0.896 \mathrm{mg} / \mathrm{L}$ for non-canned beverages while Zinc concentration was also found to range between 27.652 to $35.447 \mathrm{mg} / \mathrm{L}$ for canned and 26.649 to $42.447 \mathrm{mg} / \mathrm{L}$ for the non-canned beverages. All the samples studied have Chromium and Zinc concentrations exceeding the maximum concentration limit (MCL) as set by USEPA while 100\% of the canned beverages exceeded the (MCL) for Nickel only $93.33 \%$ of the non-canned exceeded the Nickel MCL. Levels of the metals analysed exceeded the legislative safe limits set by both United States Environmental Protection Agency (USEPA) and Standard Organization of Nigeria (SON).

Keywords: Chromium, Zinc, Nickel, Canned, Non-canned beverages.
\end{abstract}

\section{INTRODUCTION}

Heavy or toxic metals are trace metals that are at least five times denser than water. As such, they are stable elements meaning they cannot be metabolized by the body and bio accumulative passed up the food chain to human (Ademoroti, 1979).

Heavy metals are often toxic to an organism having density greater than $5 \mathrm{gcm}^{-3}$. There are many of such metals which may be discharged from industries, farmlands, municipal urban run offs etc. into surface waters to cause pollution (Ademoroti, 1979; Welch et a., 1988)

Living organisms require trace amounts of some heavy metals, e.g. Iron, Copper, and Zinc, as they are essential to maintain the metabolism of the human body, but at higher concentrations these metals can lead to poisoning and other hazards because they cannot be degraded or destroyed, and tend to bioaccumulation (Crini, 2006). Bioaccumulation means an increase in the concentration of a chemical in a biological organism over time, compared to the chemical's concentration in the environment.

Moreover, heavy metals are dangerous because they tend to accumulate in living systems thereby causing injurious effects like lung cancer, bone defects (osteomalacia, osteoporosis) in humans and animals, increase blood pressure, to the nervous system and accumulate in food chain (Alloway, 1990)

The levels of heavy metals in the commercially available beverages are unclear, therefore, this paper studied the concentration of $\mathrm{Zn}, \mathrm{Cr}$ and $\mathrm{Ni}$ in beverages and fruit drinks commonly sold in Zaria, Nigeria using Atomic Absorption Spectrophotometry, the implications of chronic effects of $\mathrm{Zn}, \mathrm{Cr}$ and $\mathrm{Ni}$ in humans was discussed.

\section{MATERIALS AND METHODS}

Sample Collection

Fifteen different samples of canned (8) and non canned (7) beverages imported and locally manufactured purchased from three different places selected at random on June 2011 in Ahmadu Bello University (ABU) Zaria, Kaduna State Nigeria were used in the study. The samples were kept at room temperature for five (5) days before the digestion.

The glass wares were washed before and after the analysis using detergent solution, $\mathrm{HCl}$ and distilled water to minimize contamination. The samples were classified into canned and non-canned drinks.

The canned products were coded C1, C2, C3, C4, C5, $\mathrm{C} 6$ and $\mathrm{C} 7$ while the non-canned products were coded as N1, N2, N3, N4, N5, N6, N7 and N8.

The samples were digested and analysed for the Chromium, Nickel and Zinc concentration using Atomic Absorption Spectrometer (Model AA 6800) according to the standard analytical methods as reported by Oriasakwe et al., 2009.

\section{RESULTS AND DISCUSSION}

The figures (1-6) above revealed the concentrations of Chromium, Nickel and Zinc in some imported and locally manufactured beverage samples obtained in Zaria, Nigeria.

The Chromium concentration levels ranged from 0.528 - $1.509 \mathrm{mg} / \mathrm{L}$ for the canned and $0.176-1.358 \mathrm{mg} / \mathrm{L}$ for non-canned beverages. Figures 1and 2 of both canned and non canned show that $100 \%$ of the canned and non canned beverages had Chromium levels that exceeded the maximum contaminant level (MCL) of $0.10 \mathrm{mg} / \mathrm{L}$ as set by United States Environmental protection agency (US EPA, 2002). 
The Nickel level ranged from $0.156-0.802 \mathrm{mg} / \mathrm{L}$ for the canned drinks and $0.125-0.896 \mathrm{mg} / \mathrm{L}$ for non-canned drinks. Figure 3 shows that $100 \%$ of the canned drinks had Nickel levels that exceeded the maximum contaminant level of $0.10 \mathrm{mg} / \mathrm{L}$ set by US EPA, while $93.33 \%$ of the non-canned drinks exceeded the MCL as shown in figure 4.

The Zinc levels ranged from $27.652-35.447 \mathrm{mg} / \mathrm{L}$ for canned and 29.649 - $42.442 \mathrm{mg} / \mathrm{L}$ for non- canned drinks. All beverages in figures 5 and 6 had Zinc levels that were above the MCL of $5.0 \mathrm{mg} / \mathrm{L}$ set by US EPA.

The concentration of Chromium determined in the Spanish study (Garcia et al., 1996) was low compared to our findings in Nigeria. More so, the contributions of non- alcoholic drinks to dietary intake of this element have been estimated to be $0.41 \mathrm{mg} /$ day in the Spanish diet. The range of value determined in the study, is obviously lower than the findings in this present study (Garcia et al., 1996).

This call for serious public health concern on the part of both the Nigerian consumers and the regulatory agencies. Since as early as the 1950's, it has been known that Chromium is essential for normal glucose metabolism. Too little Chromium in the diet may lead to insulin resistance. However, there is still no standard against which Chromium deficiency can be established. Nevertheless, Chromium supplements are becoming increasingly popular. Generally it was that toxic effects of Chromium are seldom seen; recently, however, the safety of one of the dosage forms of Chromium (Chromium picolinate) has been questioned. One should be aware that individual patients with type-2 diabetes mellitus might have an increased risk of hypoglycemic episodes when taking chromium supplement as self medication. This speculation thus rases concern for people who may end up amassing toxic level of chromium from chromic low level intake. (Orisakwe et al., 2009).

The concentration of Nickel found in this study are higher than mean values reported by for fruit drinks by Onianwa et al., 1999, also the concentration of the Nickel found in Turkey were lower compared to our findings in Nigeria. (Mehmet et al., 2010).
Maduabuchi et al., 2008, reported that $80.95 \%$ of the canned drinks had Nickel level that exceeded MCL of $0.10 \mathrm{mg} / \mathrm{L}$ while $72.41 \%$ of the non canned beverages had Nickel level exceeding the MCL. Nickel is a trace element, required in minute quantities by the human body. It is found widely in the environment and also all tissues in the human body. Though present in minute quantities, Nickel accumulates in the Kidneys, bones and thyroid gland and cause toxicity. Higher quantity of Nickel is known to be injurious for human health.

The bioavailability of Nickel and the present of constituencies that promote oxygen free radical reactions evidently influence the carcinogenicity of nickel oxides and related compound. Not all Nickel compounds are equally carcinogenic, because their carcinogenic potency is directly related to the ability to enter cells. Certain water insoluble nickel compound exhibit potent carcinogenic activity, whereas highly water soluble nickel compounds relates to their bioavailability and the ability of nickel ions to enter cells quiet efficiency via phagocytic processes. Subsequent intracellular dissolution yield very high cellular levels of $\mathrm{Ni}^{2+}$. Water soluble nickel salts do not readily enter cell. Therefore, these compounds are generally not carcinogenic in animals and, to a large extent, have not been considered potent human carcinogens, although recent studies have suggested an increase in cancer in nickel refinery areas where exposure to water soluble nickel salts occurs.

Differences in the carcinogenic activities of nickel compounds may reflect variations in their capacities to provide Nickel ion $\left(\right.$ e.g $\mathrm{Ni}^{2+}$ ) at critical sites within target cells. $\mathrm{Ni}^{2+}$ can initiate carcinogenesis, possibly by mutagenesis, chromosome damage, formation of Z-DNA, inhibit of DNA excision repair or epigenetic mechanisms.

The concentration of Zinc determined by Contreraslopez et al., 1987 was reported as $50 \mathrm{mg} / \mathrm{L}$ in fruit juice while Paolo and Maurizio, 1978 reported $0.41 \mathrm{mg} / \mathrm{L} \mathrm{Zn}$ in fruit in Italy. The level found in this study was lower than $50 \mathrm{ppm}$ but also very much higher than mean level of $0.41 \mathrm{mg} / \mathrm{L}$ reported above..

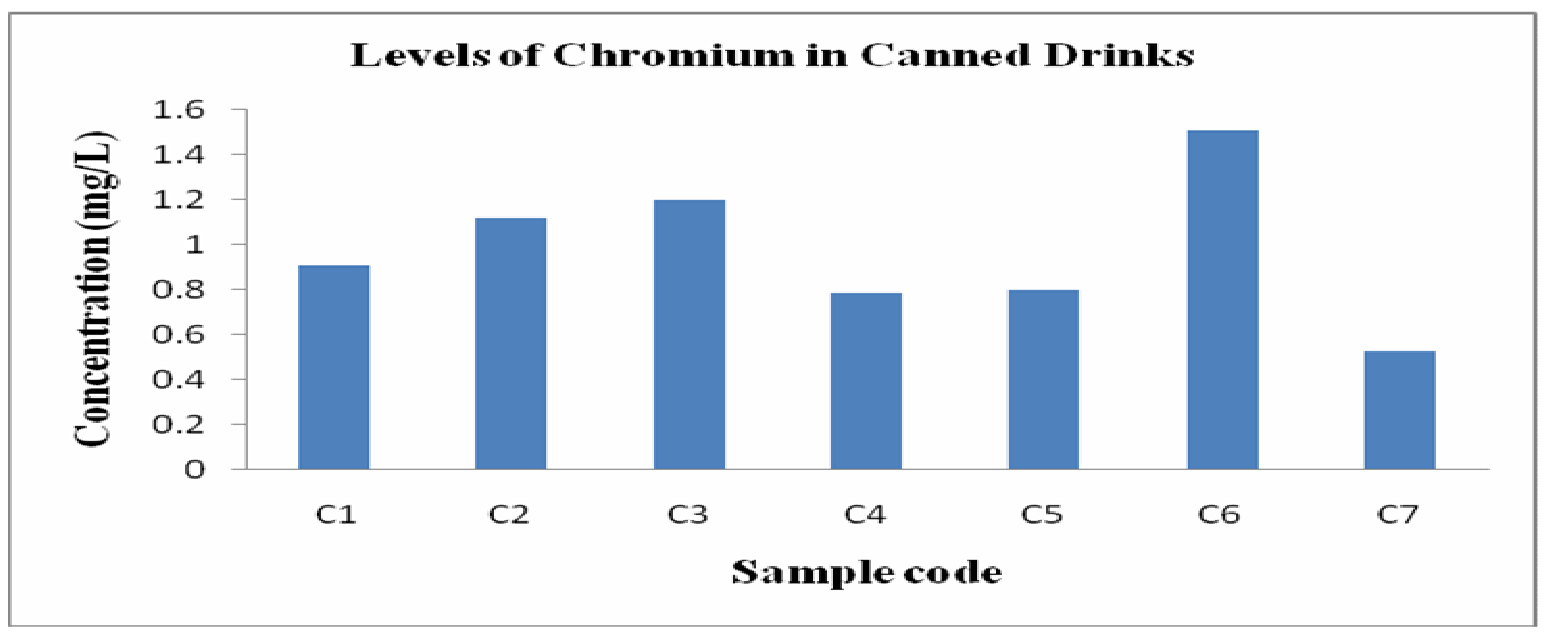

Figure 1: Showing the concentration of Chromium in the canned beverages 


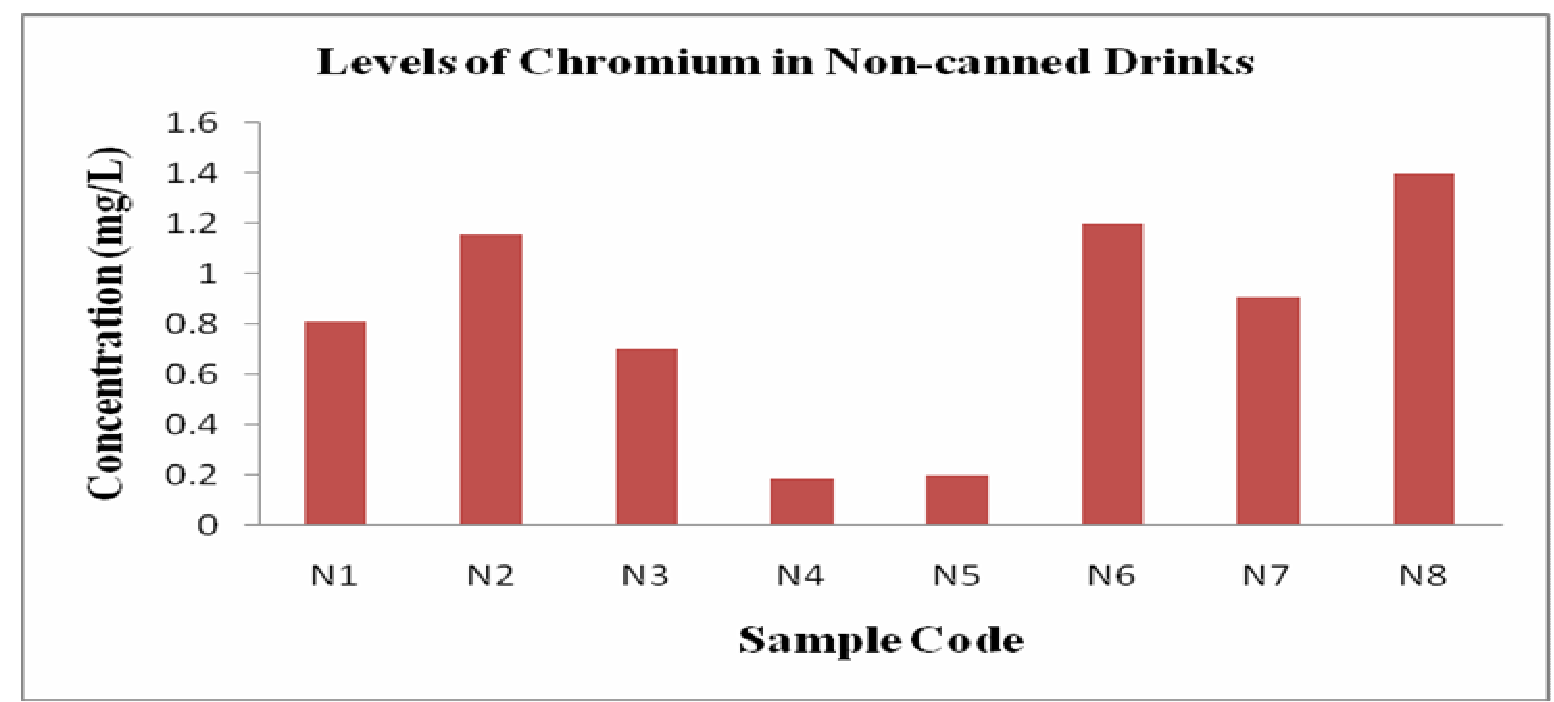

Figure 2: Showing the concentration of Chromium in the non-canned beverages

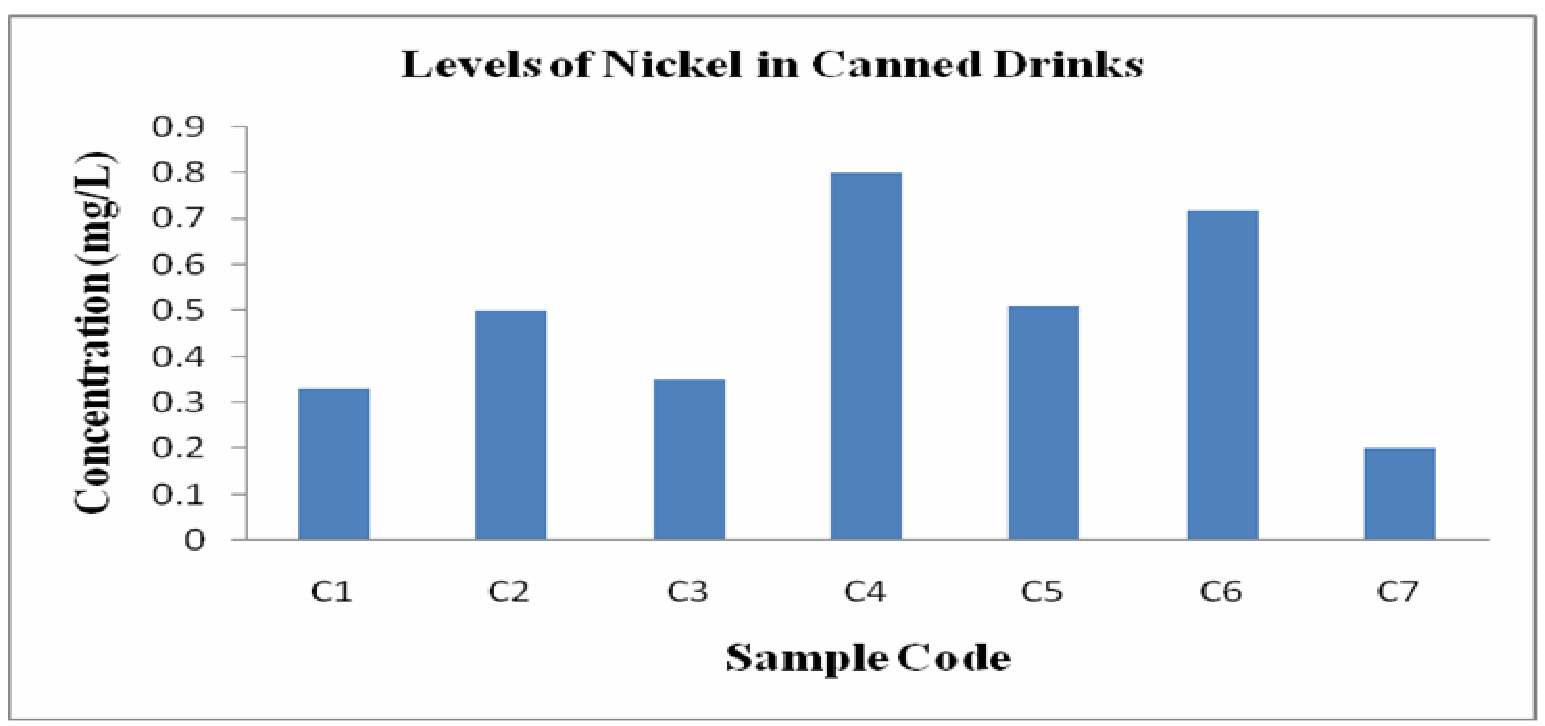

Fig. 3: Showing the concentration of Nickel in the canned beverages

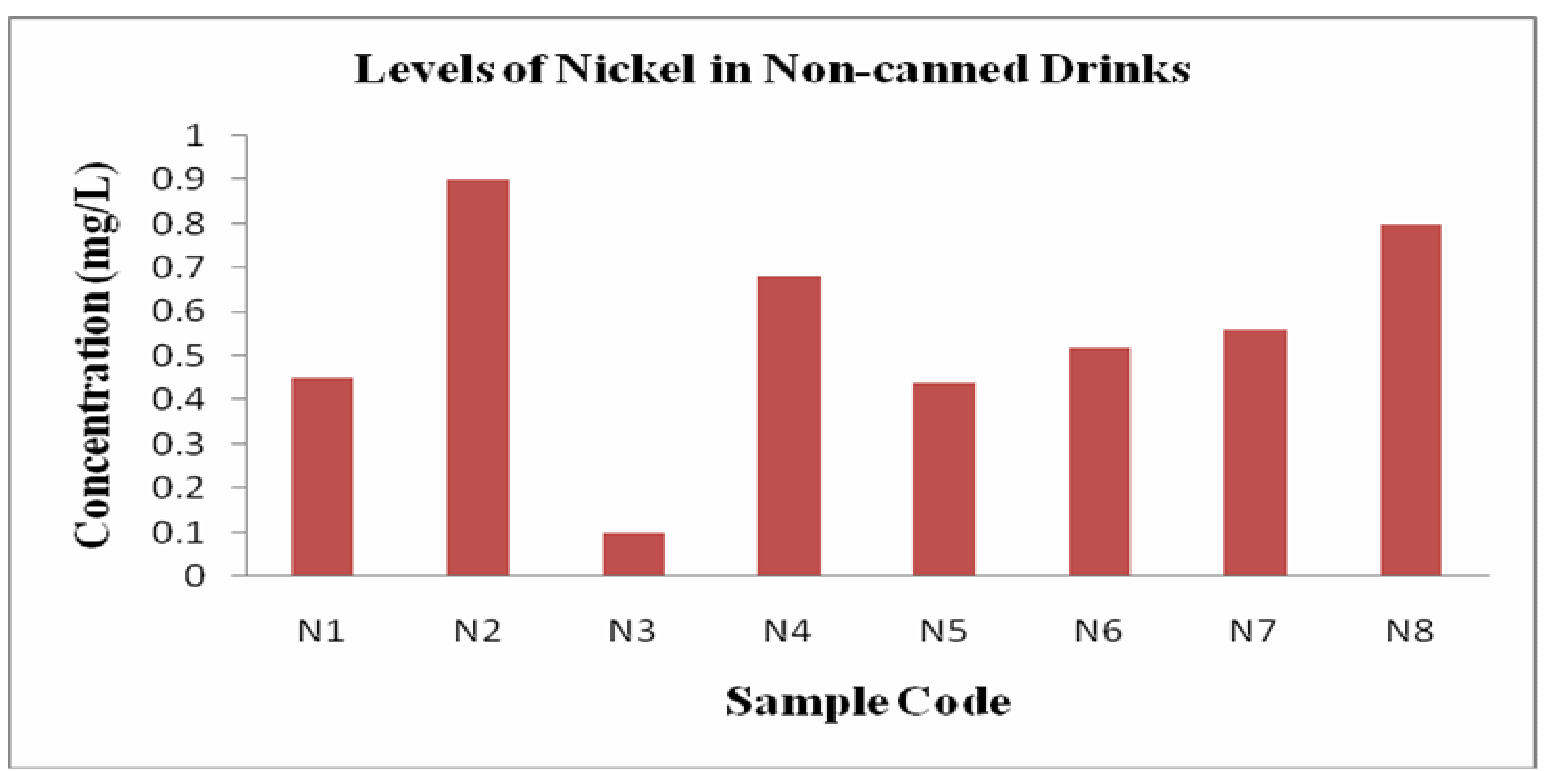

Figure 4: Showing the concentration of Nickel in the non-canned beverages. 


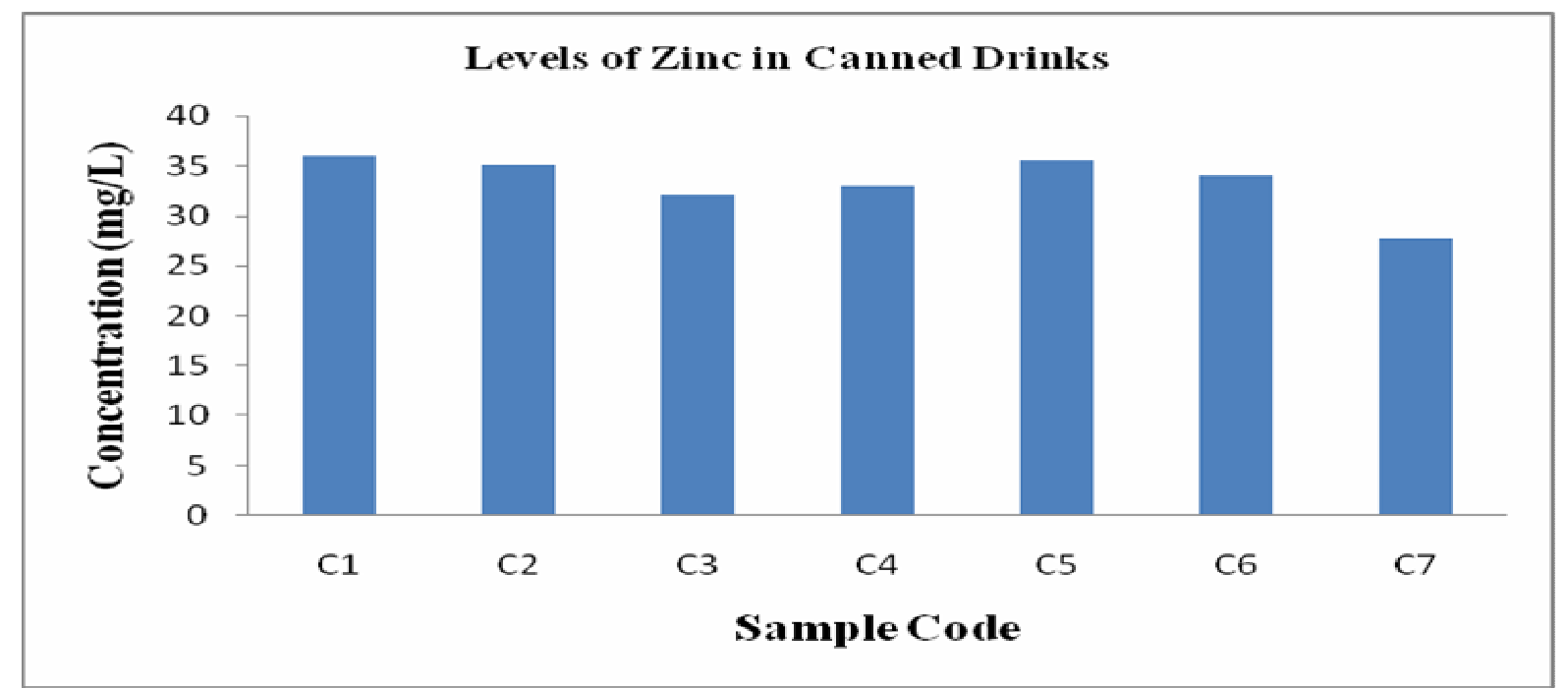

Figure 5: Showing the concentration of Zinc in the canned beverages

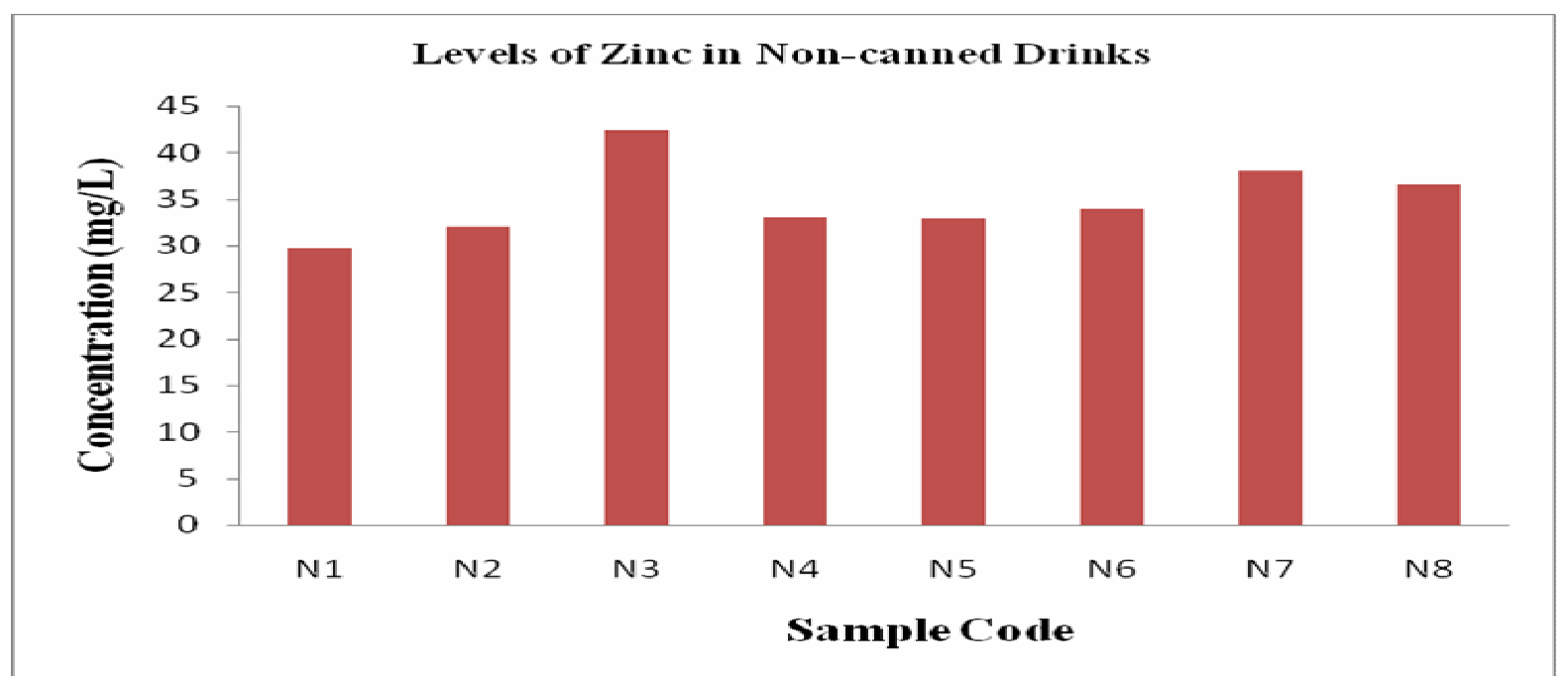

Figure 6: Showing the concentration of Zinc in the non-canned beverages

\section{CONCLUSION}

The maximum contaminant levels for the metals analysed from both canned and non-canned beverages were higher than the maximum contaminant levels set by United States Environmental Protection Agencies (US EPA) and agreed by Standard Organization of Nigeria (SON).

Though the source of these contaminants in beverages were not known or investigated in this

\section{REFERENCES}

Ademoroti, C.M.A., (1979). Studies on physicochemical methods of wastewater treatment Ph.D Thesis. University of London. pp 59-84.

Alloway, B.J., (1990): Heavy Metals in Soil, $4^{\text {th }}$ Edition. pp154.

Contrelaslopez, C.A., Lianaza, C.A. and Santamaria, D.P., (1987). Metal content of apple juice for cider in Asturia (Spain). Afinidad, 44: 502503.

Crini, G., (2006). Non-conventional low-cost adsorbents for dye removal. Biores. Tech. 97, 1061-1085. research, it is advisable that consumers of beverages should reduce the amount of their daily consumption since this high concentration of heavy metals could lead to complication and even death. In view of this, all the steps involved in the production of beverages should be closely monitored to avert contamination by heavy metals.

Garcia, R., Maiz, I. and Millan, E., (1996). Heavy metal contamination analysis of roadsoils and grasses from Gipuzkoa (Spain), Env. Tech. 17(7): $63-770$.

Maduabuchi J.M.U., Nzegwu, C.N., Adigba, E.O., Oragwu, C.I., Agbo, F.N., Agbata, C.A., Ani, G.C. and Orisakwe, O.E., (2008). Iron, manganese and nickel exposure from beverages in Nigeria: a public health concern? J. Health Sci. 54(2): 335-338. 
Mehmet, B., Gulderen, Y.B., and Ayhan, O., (2010). Determination of some heavy metals levels in soft Drinks from Turkey. Analyst. 28 (3): 213-217.

Norseth T., (1997). Handbook on the Toxicology of Metals, Volume II : Specific Metals, 2nd edn. Friberg, L., Nordberg, G., and Vouk, V., Eds., Elsevier Science Publishers, Amsterdam, 1986. Von Burg R., "Nickel and some nickel compounds", J. Appl. Toxicol. 17(6): 425431.

Onianwa, P.C., Adetola, I.G., Iwegbue, C.M.A., Ojo, M.F. and Tella, O.O., (1999). Trace metals composition of some Nigerian beverages and food drinks. Food Chem. 66: 275-279.

Orisakwe, O.E., Oragwu, C.I., Maduabuchi, J.M.U., Nzegwu, C.N. and Nduka, J.K.C., (2009). Copper, selenium and zinc content of canned and non-canned beverages in Nigeria . Int. J. Environ. Res. Public Health 3(1): 42-49

Paolo, B. and Maurizio, C., (1978). Simultaneous determination of copper, lead and zinc in wine by differential pilse polarography. Analyst. 107: 271-280.

Standard Organisation of Nigeria (SON) (2003). Inorganic Constituents for drinking Water Quality.

United States Environmental Protection Agency (US EPA) Washington, D.C., (2002). "The National Water Quality Inventory: Report to congress for the 2002 reporting cycle-A profile. Retrieved July 16, 2009.

Welch, A.H, Lico, M.S. and Hughes, J.L., (1988). Arsenic in ground water of the western United States. Ground water, 26: 333-347. 